To cite: AA Khalil 'The direct application of the Constitution by ordinary courts and the concept of Shari'a as a source of legislation: A review of the Sudanese Supreme Court's decision in Sudan Government V ASK' (2017) 17 African Human Rights Law Journal 460-472 http://dx.doi.org/10.17159/1996-2096/2017/v17n2a6

\title{
The direct application of the Constitution by ordinary courts and the concept of Shari'a as a source of legislation: A review of the Sudanese Supreme Court's decision in Sudan Government v ASK
}

\author{
Ali Abdelrahman Khali** \\ Fellow, Assistant Professor of Law, University of Khartoum, Sudan
}

\begin{abstract}
Summary
This is a review of the 2011 decision of the Sudanese Supreme Court in Sudan Government v ASK. Relying on article 5(1) of the Sudanese Constitution 2005, which states that Shari'a should be the source of legislation, the Court decided to disregard the provision in section 4 of the Child Act 2010, which defines the child as a person whose age does not exceed 18 years, as unconstitutional as it was in conflict with the Criminal Act 1991, derived from Shari'a, that defines an adult as a person whose puberty is established by apparent features and has reached 15 years of age. While the article argues that the decision reaffirms the power of the ordinary courts to refrain from applying unconstitutional legislation even with the existence of a specialised Constitutional Court, it argues that in this specific case there was neither a violation of Shari'a nor of the Constitution that justifies invoking this power.
\end{abstract}

Key words: Shari'a; childhood; definition of child; Sudan Interim National Constitution; source of legislation

LLB LLM (Khartoum) LLM (London); ali.khalil@sksadvocates.com. The author thanks Lutz Oette, Mutasim Al-Agraa, Nabil Adib, Alsamawal Idris and the anonymous reviewers for their valuable comments on the first drafts of this note. 


\section{Introduction}

Sudan Government $v A S K^{1}$ is a criminal case which initially required the interpretation of two conflicting provisions in the Criminal Act 1991 and the Child Act 2010. The Sudanese Supreme Court found that the provision in the Child Act 2010, which defines a child as a person whose age does not exceed 18 years, ${ }^{2}$ was in conflict with the Criminal Act 1991, derived from Shari'a, which defines an adult as a person whose puberty is established by apparent features and who has reached 15 years of age. ${ }^{3}$ Therefore, the Court concluded that, based on article 5(1) of the Sudan Interim National Constitution 2005 (INC), which states that Shari'a should be the source of legislation, ${ }^{4}$ the provision in the Child Act was unconstitutional. Accordingly, the Court decided to disregard that provision and to base its judgment on the Criminal Act.

This decision raises two important issues. The first is the direct application of the Constitution by ordinary courts even with the existence of a specialised Constitutional Court. The second issue is the concept of Shari'a as a source of legislation and how this is conceived and interpreted by Sudanese courts. The article examines the Court's reasoning and addresses these two questions with reference to the relevant constitutional, legislative and jurisprudential framework. These two issues have a significant impact on the protection of the Bill of Rights in Sudan.

\section{Facts}

The facts of this case, as summarised by the Supreme Court, are as follows: The accused, a 19 year-old man, was put on trial for the alleged rape of the victim causing her illegitimate pregnancy. During the pre-trial investigation, the girl admitted that sexual intercourse had taken place with her consent. However, the charge was changed from adultery ${ }^{5}$ to rape because of her age. She was 17 years old, which means that based on section 4 of the Child Act, she was a child, and according to section 3 of the Criminal Act 1991, the consent of a minor is not valid. Therefore, the act committed would

(2011) SLJR 75.

2 The Child Act 2010 provides in sec 4, in Interpretations, that a child means 'every person, who is not above the age of eighteen years'.

3 Sec 3 defines an adult as 'a person whose puberty has been established by definite natural features and has completed fifteen years of age. Whoever attains eighteen years of age shall be deemed an adult even if the features of puberty do not appear.'

4 Or rather, a source of legislation, as later argued.

5 Sec 145(1) of the Criminal Act 1991 provides: 'There shall be deemed to commit adultery (a) every man, who has sexual intercourse with a woman, without there being a lawful bond between them; (b) every woman, who permits a man to have sexual intercourse with her, without there being a lawful bond between them.' 
fall within the definition of statutory rape as stipulated in section 149(1) of the Criminal Code $1991^{6}$ which, if committed against a child, is severely punishable under the Child Act 2010, namely, by the death penalty or life imprisonment.

Thus, the Court had to answer the question whether or not the alleged victim was a child. If she was considered an adult, both she and the accused would be charged with adultery, but if she was found to be a child, the accused would be accused of having raped her. ${ }^{7}$

\section{Decision}

The court of first instance referred to the ordinary statutory interpretation rules and, accordingly, decided that the provisions of the Child Act 2010 as subsequent legislation should prevail over the provisions of the preceding Criminal Code of 1991. ${ }^{8}$ Therefore, the court ruled that the alleged victim was a child and, therefore, that her consent was invalid. Accordingly, the court convicted the accused of rape and sentenced him to 20 years' imprisonment. This judgment was upheld by the Court of Appeal.

When brought before the National Supreme Court for confirmation, this Court reached a different conclusion. It reversed the ruling of the lower courts, deciding that the provision in section 4 of the Child Act 2010, which sets the age of majority at 18 years, was in conflict with the Criminal Act 1991 that sets the age at 15 years plus physical features of puberty or 18 years in all cases. Thus, the provision of the Child Act is unconstitutional as the Criminal Act is derived from Shari'a, and article 5(1) of the INC provides that '[n]ationally-enacted legislation having effect only in respect of the northern states of the Sudan shall have as its sources of legislation Islamic Shari'a and the consensus of the people'. Accordingly, the Court decided to disregard the provision in the Child Act and to base its ruling on the Criminal Act. Hence, the Court concluded that the alleged victim was an adult as her puberty had been established by her pregnancy. Therefore, the Supreme Court quashed the conviction

6 Sec 149(1) stipulates that '[t]here shall be deemed to commit the offence of rape, whoever makes sexual intercourse, by way of adultery, or sodomy, with any person without his consent'. However, in February 2015 this provision was amended to provide that rape will also be deemed to have been committed whenever someone has had sexual intercourse with a person who cannot express her consent because of her age.

7 Adultery is punishable by 100 lashes for unmarried persons according to sec 146 of the Criminal Act 1991.

8 Sec 6(3) Interpretation of Laws and General Clauses Act 1974. 
of rape and ordered the retrial of the accused on a charge of adultery. ${ }^{9}$

The Court referred to section 6(2) of the Interpretation of Laws and General Clauses Act 1974 which states that '[i]f any provision in any law is inconsistent with any provision of the Constitution, the provision of the Constitution shall prevail to the extent of such inconsistency'.10

The facts of the case per se do not entail any interpretation of the Constitution. However, the Supreme Court resorted to this constitutional provision to resolve the inconstency between the provision in the Criminal Act 1991 and the provision in the Child Act 2010 which both were in force.

\section{Background}

\subsection{Direct application of the Constitution by ordinary courts}

The direct application of the Constitution by ordinary courts refers to the power, or duty, of ordinary courts to refrain from applying unconstitutional legislation. In some countries where a European centralised system of constitutional judicial review is followed, and even with the existence of a specialised Constitutional Court as the sole organ that can determine constitutional issues, an ordinary court, when it finds that the Constitution expressly overrides a provision in an ordinary law, can disregard that law and decide the case on the basis of the Constitution. In this case, the judgment of the ordinary court is considered to be neither a determination of a constitutional issue nor an exercise of 'proper' judicial review over the constitutionality of laws. Rather, it is merely a direct application of the Constitution. The judgment will not be erga omnes, that is, its effect will be restricted to the parties to the dispute and will not extend to annul the unconstitutional provision. This approach is followed in a number of countries, including Portugal, Russia, Columbia and Egypt. ${ }^{11}$

In Sudan, the Constitutional Court has exclusive power to review the constitutionality of legislation and to strike down unconstitutional

9 The Court held that the prosecution had at the outset wrongfully excluded the girl from accusation and, therefore, there was no way to then include her in the trial as an accused (80).

10 Sudan Government v ASK (n 1 above) per Abusin Deputy CJ 80.

11 AF Serour The constitutional protection of rights (2000) 219 (in Arabic); A Cortes \& $T$ Violante 'Concrete control of constitutionality in Portugal: A means towards effective protection of fundamental rights' (2010-1) 29 Penn State International Law Review 759 761, where they stated that '[o]rdinary courts shall not apply rules that are inconsistent with the constitutional provisions or principles. This means that there is a duty on the judiciary not to enforce rules that are in opposition to the Constitution.' However, '[o]nly the Constitutional Court has competence for the abstract control of constitutionality, which means that it is within its exclusive jurisdiction to declare a provision is unconstitutional with general binding force'. 
legislation. However, the lower courts have the power to apply and to interpret the Constitution in the ordinary course of disposing ordinary cases brought before them as long as the constitutional law in question is clear. This approach has its basis in article 128 of the INC, in the chapter governing the national judiciary, ${ }^{12}$ which stipulates that '[j] ustices and judges shall uphold the Constitution and the rule of law'. ${ }^{13}$ This is further supported by article 48 of the INC, which states that ' $[\mathrm{t}]$ he Bill of Rights shall be upheld, protected and applied by the Constitutional Court and other competent courts'. It is submitted that upholding, protecting and applying the Constitution by 'other competent courts' necessarily implies the disregard by these courts of unconstitutional legislation. This power of ordinary courts to directly enforce constitutional norms has been supported by the Constitutional Court in an obiter dictum in Masarat Media Co Ltd and Accord Services Co Ltd v National Security and Intelligence Service. ${ }^{14}$

This is compatible with section 6(2) of the Interpretation of Laws and General Clauses Act 1974 which provides for the dominance of the Constitution over inconsistent legislation. It is obvious that this provision addresses ordinary courts. The fact that this Act was passed in the era preceding the establishment of a specialised Constitutional Court should not be of significance as at that time constitutional judicial review had also been exercised centrally by a specialised chamber of the Supreme Court.

What adds considerable weight in support of this approach is that neither the INC nor the Constitutional Court Act 2005 provides for a concrete judicial review procedure through which an ordinary court can halt the proceedings before it and refer the issue to the Constitutional Court to decide on the constitutionality of the debated provision. This leaves the ordinary courts with no option but to proceed with handling the constitutional issue in this limited scope.

This power of direct application of the Constitution was exercised by the Supreme Court in Abdulla El Tayeb Osman v Mohammed Osman El Tayeb, ${ }^{15}$ where the Court ignored a provision in the Civil Transactions Act 1984 which purports to oust the jurisdiction of the

12 The national judiciary is composed of the ordinary courts as opposed to the Constitutional Court for which another chapter of the INC is assigned.

13 Art 128(3). It corresponds to art 101(2) of the Sudanese Constitution of 1998, under which the Constitutional Court was first established in Sudan, which stipulates that a judge of ordinary courts 'shall be guided by the principle of the supremacy of the Constitution and the law and he shall protect this principle'.

14 (2006-2010) Sudan Constitutional Court Law Reports 550570 per Somi Zaidan J.

15 Civil Cassation 433/2001, Supreme Court Khartoum (unreported). The Court decided that sec 559(6) of the Civil Transactions Act 1984, which precludes courts from hearing any suit brought against the government or against the registered owner of a land regarding any matter relating to the ownership of any investment land, violated the right of access to court which is protected by art 31 of the Sudanese Constitution of 1998. The Court, therefore, decided to disregard this provision and to proceed hearing and determining the dispute on the basis of the Constitution. The Court acknowledged that it did not have the power to annul such a provision, but affirmed its power to refrain from applying it. 
courts to hear and determine certain types of disputes over government land. The Supreme Court deemed the provision unconstitutional and decided to exercise jurisdiction over the dispute as a direct application of the constitutional right to litigate. In addition to section $6(2)$ of the Interpretation of Laws Act, the Court referred to its earlier decision in Nasr Abdelrahman $v$ The Legislative Authority, ${ }^{16}$ where it decided that in case of a conflict between any provision of any law and the Constitution, courts should ignore the provision of the law and refrain from its application. ${ }^{17}$

In principle, this approach is well supported by the constitutional, legislative and jurisprudential framework. It is submitted that the approach may be considered an important safeguard for ensuring constitutionalism and respect of constitutional rights, especially in countries where the Constitutional Court is highly politicised and less independent compared to the judiciary. The experience illustrates that the Sudanese Constitutional Court is reluctant to exercise its power to strike down unconstitutional legislation on issues the government deems as touching upon its remit. ${ }^{18}$ Therefore, this approach allows ordinary courts to avoid the application of unconstitutional provisions in a limited scope, that is, as between parties in specific cases. After the adoption of the INC in 2005, more than 60 laws were identified as infringing the Bill of Rights and, accordingly, as unconstitutional. Although many recommendations were made to amend these laws to bring them into conformity with the Constitution, in fact very little has realised. ${ }^{19}$ Therefore, it is submitted that in the absence of the political will to amend these unconstitutional provisions, this power of the ordinary courts should be a basis for avoidance of the application of those provisions and, hence, an important safeguard for the protection of constitutional rights.

Of course, the application of this approach is limited by the principle that the unconstitutionality of the provision in question should be obvious, and there should not be a contrary ruling in the matter by the Constitutional Court. In other words, the constitutional law on the matter should be obvious and clear. According to section 24(1) of the Constitutional Court Act 2005, judgments and decisions of the Constitutional Court are binding on all state organs in Sudan, including ordinary courts.

16 (1974) SLJR 74.

17 This decision was passed in 1974 when the Supreme Court was the 'custodian of the Constitution' under the Constitution of 1973 and before the adoption of the Constitutional Court system in 1998. However, it remains relevant as the constitutional judicial review was centrally entrusted to a specialised chamber within the Supreme Court.

18 See eg Kamal Saboun $v$ Sudan Government (2006-11) Sudan Constitutional Court Law Reports 123.

19 See A Teir \& B Badri (eds) Law reform in Sudan: Collection of workshop papers (2008). 


\subsection{Shari'a as a source of legislation}

It appears that the English version of article 5(1) of INC, which provides for Islamic Shari'a and the consensus of the people as sources of legislation, differs from the Arabic one; the translation is not accurate. In the Arabic version of the Constitution, the word 'sources' is used without a definite article which means that it is not intended to be the sole sources of legislation. However, in the English version, this was translated in a manner that suggests that Shari'a and consensus are the exclusive sources of legislation: 'shall have as its sources of legislation Islamic Shari'a and the consensus of the people'. 20

In all cases, Shari'a is not the only source of legislation; the consensus of the people is another independent source according to article 5(1) of the Constitution. However, it is not clear how this consensus can be established; whether through referendum or just by way of an Act of parliament, customary law or otherwise. As long as the Constitution does not provide for any mechanism to establish the consensus of the people, one may wonder whether the legislature may replace that mechanism, that is, whether the will of the legislature can act as the criterion of the consensus. Further, it is also not clear whether the consensus of the people, however it may be established, is enforceable even if it is inconsistent with Shari'a norms.

As to the effect of such a provision, Lombardi states that '[i]t might seem logical to assume that a decision to adopt an SSL [Shari'a as a source of legislation] clause making Shari'a something less than "the chief source" indicates an intention not to be bound by any firm prohibition on legislation inconsistent with Shari'a'. ${ }^{21}$ Similarly, the jurisprudence of the constitutional courts in countries adopting similar provisions shows that such a provision in the Constitution is not a basis for striking down inconsistent legislation. ${ }^{22}$

It is submitted that even if Shari'a is considered the only source of legislation, the outcome would not be certain. It may be inferred that the drafters of the INC did not intend to vest the Constitutional Court or the judiciary with the power to strike down legislation which is inconsistent with Shari'a norms. If they intended this result, they would have used wording similar to that of the equivalent provision in the preceding Constitution of 1998, where it was explicitly stated that

20 However, both versions are authoritative; art 223 INC.

21 CB Lombardi 'Constitutional provisions making Shari'a "a" or "the" chief source of legislation: Where did they come from - What do they mean - Do they matter' (2012) 28 American University International Law Review 733768.

22 Eg, the Kuwaiti Constitutional Court held that art 2 made Shari'a 'a source' and not 'the only source' of law so that the legislator could adopt rules which may be considered inconsistent with traditional Shari'a. J Goldenziel 'Veiled political questions: Islamic dress, constitutionalism, and the ascendance of courts' (2013) 61 American Journal of Comparative Law 35-36. See also Lombardi (n 21 above). 
'no legislation in contravention with these fundamentals shall be made'. ${ }^{23}$ To the same extent, article 114 of the Draft Constitution of 1968 clearly stated that '[e]very legislation passed after the adoption of this Constitution in contravention with the provisions of Kitab and Sunnah should be void'. In the absence of such wording, one may reasonably assume that such a provision should not operate as a basis for striking down non-Shari'a-compliant legislation.

The term Shari'a per se is vague and susceptible to different interpretations. ${ }^{24}$ Shari'a is commonly mistaken for Figh; many use these two terms interchangeably. To avoid plunging into this conceptual muddle, it is important at least to distinguish Fiqh as the detailed jurisprudence developed over centuries by Islamic scholars. ${ }^{25}$ In this context, it has been reaffirmed in many cases by the Sudanese Supreme Court that what was meant by the term Shari'a is the conclusive provisions contained in the Quran and Sunna and not the detailed Fiqh opinions even if delivered by eminent Muslim jurists. ${ }^{26}$

Similarly, it is well settled among Islamic scholars in Egypt and in the jurisprudence of the Constitutional Court there that what is meant by Shari'a as the source of legislation is the fundamental general principles agreed upon by the different schools, excluding the detailed rules that may change from one environment to another. ${ }^{27}$ Whether or not this is a useful criterion is still open to further debate.

In obiter dicta it seems that the Sudanese Constitutional Court is going in the same direction. ${ }^{28}$ According to EA Eljail J, the prevailing opinion in the Constitutional Court is that it is not concerned with the extent to which a statute is consistent with Shari'a because article 5(1) addresses the legislature. Therefore, there is no way for the Constitutional Court to intervene to review the consistency with Shari'a unless there is a specific conclusively-established and indicative text of Shari'a (Qat' 'iy-uth-Thubūt and Qat' '̀y-ud-Dalālah). ${ }^{29}$ This has been reaffirmed by two other judges, AE Elbasheir J, the Chairperson of the Court, and Somi Zaidan J, although differently worded, adding that article 5(1) can be invoked only if the right allegedly infringed

\footnotetext{
23 Art 65.

24 According to Cardozo, '[a] good deal of warfare has its origin in the confusion that arises when a single term of a broad and ill-defined content is made to do duty for two or more ideas'; BN Cardozo The growth of the law (1966) 30.

25 See eg MA Hussein Islamic Figh: The chief source of legislation (1999) (in Arabic) 1618.

26 Abdelwahab M Yousuf $v$ Mohammed E El-Amin (1992) SLJR 301. This has been reaffirmed by the Constitutional Court in Adam Musallam v SG (2012) Sudan Constitutional Court Law Reports 283 288, where it was stated that what was meant by Shari'a was the divine texts included in the Quran and Sunna, whereas the Figh is a mere human endeavour.

27 Hussein (n 25 above) 8.

28 Faroug M Ibrahim v The Government of Sudan (2006-2010) Sudan Constitutional Court Law Reports 365. Ibrahim (n 28 above) 372.
} 
relates to an agreed-upon Shari'a rule and not rules that are subject to endeavour by scholars. 30

In spite of the contradiction in or, at least, the inaccuracy of these statements, which the limited scope of this article does not allow us to indulge in, it is at least settled that article 5(1) cannot be invoked to strike down legislation that adopts one of the different opinions within Islamic Figh. Therefore, the courts do not have the power to intervene with the choice of the legislature.

There is even doubt about the justiciability of article 5(1). According to Abdalla, although the provision that 'the provisions contained in this chapter are not by themselves enforceable in a court of law' applies to Chapter 2 of the INC, the principles expressed herein are basic to governance and 'the state is duty-bound to be guided by them, especially in making policies and laws'. The unjustifiability should rather attach to the entire general principles of the INC, including article 5(1). ${ }^{31}$

\section{Analysis of the reasoning}

It is submitted that although, in principle, this approach of direct application of the Constitution is jurisprudentially well supported, its application in this case was not. There was neither a violation of the Constitution nor of Shari'a that justifies the application of this approach. The Court's reasoning seems unsound for a number of reasons.

\subsection{Lack of diligence in rendering the judgment}

This judgment was delivered per incurium. The Supreme Court disregarded binding precedents of the Constitutional Court. It ignored the decision in Najmeldin Gasmelseed v 'Awlia dam' Abdelrahim M Ali, ${ }^{32}$ in which the Constitutional Court upheld the constitutionality of a similar provision in the Child Act 2004 that similarly defined a child as not exceeding 18 years of age. ${ }^{33}$ The Constitutional Court considered both issues in detail in its ratio decidendi: the issue of constitutionality of the provision that set the majority age at 18, as well as the issue of Shari'a as a source of legislation, and concluded by upholding the constitutionality of the provision. It even followed its earlier decision in Abdelmouiz Hamdoun v SG. ${ }^{34}$

\footnotetext{
$30 \quad$ Ibrahim 376380.

31 Nabil Adib Abdalla, Senior Advocate, personal interview 23 October 2015.

32 (2006-2010) Sudan Constitutional Court Law Reports 399.

33 This conclusion was recently reaffirmed by the Constitutional Court in Salih $\mathrm{H}$ Jad Karim \& Others v SG and Awlia' Dam Ali Hammad \& Others CC/CC/51/2013 delivered 19 November 2014.
}

34 (1999-2003) Sudan Constitutional Court Law Reports 93. 
Therefore, it would not be easy to accept this lack of diligence in delivering the judgment by a panel of the Supreme Court presided over by the then Deputy Chief Justice of the Sudan who, shortly thereafter, became the Chief Justice of the Sudan with the current Deputy Chief Justice as a member of the panel who delivered the first judgment. ${ }^{35}$ Further, and as long as the Constitutional Court has expressed its opinion on the constitutionality of the provision in question, it may amount to usurpation of jurisdiction for the Supreme Court to deviate from this ruling.

\subsection{Violation of Shari'a and the Constitution}

The Court disregarded the fact that the opinion within the Islamic Fiqh, declaring 15 years of age plus apparent features of puberty as the criteria of adulthood, which was adopted by the legislature of the Criminal Act 1991, is not the only available opinion even within the orthodox Islamic Figh. Therefore, it cannot readily be assumed that this opinion represents Shari'a. There are different views within the four Sunni schools of Shari'a on establishing the age of majority or the age of criminal liability. The option of 18 as the age of adulthood is actually based on the Hanafi and Maliki schools, and there are many other opinions within the traditional Islamic jurisprudence. ${ }^{36}$ Therefore, and according to what has been posited above, selecting of any of these different views cannot by any means be considered a violation of Shari'a. This is obvious, and has also been discussed clearly by the Constitutional Court in the case of Najmeldin referred to. ${ }^{37}$

The Court did not explain how the Criminal Act was considered Shari'a law. Even if the provisions of the Criminal Act were derived from Shari'a, or Figh, they do not form part of the Constitution for the Court to determine the constitutionality of other laws by reference to it. The constitutionality of a statute cannot be reviewed by reference to a similar statute. Also, there should be a flagrant contradiction to the Constitution; the unconstitutionality of the relevant provision should be obvious and not reasonably disputed as posited earlier.

\subsection{A possible solution}

It is understandable that the Supreme Court endeavoured to alleviate the situation of the accused who, apparently, was relatively of the same age as the alleged victim of rape and in circumstances leading

35 The Constitutional Court's decision in Najmeldin was delivered on 2 December 2008 while the decision of the Supreme Court in this case was delivered on 30 May 2011. Therefore, the fact that Najmeldin was only published as a reported case in 2011 is probably not an excuse. The Chief Justice, or the judiciary, is served with all decisions of the Constitutional Courts on constitutional suits based on judicial decisions. However, one cannot negate the effect of the defective lawreporting system in Sudan. Throughout the 18 years of the existence of the Constitutional Court, only three volumes of law reports have been issued.

36 A Auda The modern cyclopedia of Islamic criminal Fiqh (2001) 377.

37 Najmeldin (n 32 above). 
to a reasonable inference that they were in a consensual relationship. It is submitted that this result could have been reached without addressing the issue of constitutionality of the provision of the Child Act 2010.

A possible solution would have been to rely on the ordinary rules of interpretation of statutes applicable to cases of conflict between two pieces of legislation, as provided for in the Interpretation of Laws and General Clauses Act 1974. Section 6(4) states that '[a]ny special law or any special provision in any law in respect of any matter shall be deemed an exception to any general law or general provision in any law governing such matter'. For the purpose of establishing the consent which would act as a defence in the crime of rape, the provision in the Criminal Act 1991 that provides for the age of adulthood could have been considered a special provision that prevails over the general provision in the Child Act which sets the majority age at 18 . This is because when the legislator of the Criminal Act set the proviso of consent as an exception from criminalising what would be the actus reus of rape, he meant consent of an 'adult' as defined in the same Criminal Act. Even the accused would be entitled to reasonably think so. It is more appropriate to define the degree of adulthood which is required to render consent effective by reference to the same statute that provides for the crime and the available defences and not by reference to an external text.

This approach is supported by the rule of lenity which requires that an ambiguity in a criminal statute, in prohibition or in penalties, should be resolved in favour of the accused. This rule of construction requires courts when facing a set of inconsistent punishments to resolve the ambiguity in favour of the more lenient punishment. ${ }^{38}$

This interpretation could also be fostered by adhering to the purposive approach of statutory interpretation as provided for in section $6(1)$ of the Interpretation of Laws Act 1974. This sub-section provides that '[t]he provisions of every law shall be construed in such manner as to achieve the purpose for which it has been enacted and in all cases the construction which achieves such purpose shall be preferred to any other construction'. The Child Act intends to protect minors from sexual abuse by adults, a situation that is unlikely to exist between persons of a relatively similar age as in this case. ${ }^{39}$ This approach could also have been supported by invoking the rule of avoiding absurdity, that the legislature did not intend an absurd or unjust result. It might be absurd, or unjust, for a partner in the same act who was more or less of a similar age as that of the other partner in circumstances which suggest it was a consensual and continuous relationship to end up with a 20 years jail sentence while the other partner is released and converted to a victim.

38 See Z Price 'The rule of lenity as a rule of structure' (2004) 72 Fordham Law Review 885.

39 See the General Principles of the Child Act 2010 sec 5. 
However, the article by no means addresses the adequacy of this corporeal punishment of flogging for adultery as provided for in section 146 of the Criminal Act 1991, nor does it indulge in the discussion of the issue of criminalising or decriminalising the act of consensual pre-marital sexual intercourse per se. These issues need to be adequately addressed under separate cover. Rather, the article explores the available solutions in such situations within the existing applicable laws.

In the same vein, these issues have not been addressed in light of the obligations of Sudan under the relevant international conventions to which Sudan is a party. ${ }^{40}$ Article $27(3)$ of the Sudan Interim National Constitution provides that '[a]ll rights and freedoms enshrined in international human rights treaties, covenants and instruments ratified by the Republic of the Sudan shall be an integral part of this Bill'. Although this provision intends to render the relevant international human rights conventions self-executing and to incorporate these international rights into Sudanese municipal law, its practical implementation was controversial and unfortunate. In practice, the Constitutional Court manoeuvred a flimsy reasoning to avoid the application of this provision in the few cases in which this provision was invoked. ${ }^{41}$ Therefore, although these issues are worth addressing, the discussion was confined to the relevant possible solutions to the Court within the applicable framework. The facts of the case do not raise issues of child rights. The issue was whether the consent of the 17 year-old girl was valid or not.

Article 1 of the Convention of the Rights of Child (CRC), which has been ratified by Sudan, states that '[r] or the purposes of the present Convention, a child means every human being below the age of eighteen years unless under the law applicable to the child, majority is attained earlier'. Therefore, fixing the age of majority at 15 plus puberty features does not violate the Convention and, accordingly, does not entail the relevance of the international norms in this area. The only mandatory provision referring to the age of 18 is the provision of article 37 of the CRC which forbids imposing capital punishment on persons under 18. The INC is in line with this provision and it was not an issue in this case.

\section{Conclusion}

To conclude, the judgment was poorly reasoned. Although it has been asserted that it was a reaffirmation of the power and duty of ordinary courts to refrain from applying unconstitutional legislation, there was no ground for using this approach in this specific case. This

40 See eg Doebbler v Sudan (2003) AHRLR 153 (ACHPR 2003).

41 See Izzeldin Elhaj Elmakki v Sudan Government (2011) Sudan Constitutional Court Law Reports 360. 
power should be used cautiously; the violation of the Constitution should not be reasonably disputed; and there should not be a Constitutional Court precedent to the contrary on the issue. It has been submitted that the same result of relieving the accused of the unreasonably harsh punishment for the alleged rape could have been reached by reference to the rules of interpretation of statutes without addressing the constitutionality of the Child Act provision and without basing the decision on this bewildering 'Shari'a as a source of legislation clause'. The sound application of this power of ordinary courts may be an effective tool for the protection of the constitutional rights in specific cases where legislation overtly contravenes the Bill of Rights.

The significance of the case is that it seems to be the only reported case on this approach of abstention from application of unconstitutional laws in this era starting from the adoption of the specialised Constitutional Court system in Sudan. As such, the Supreme Court paved the way for the ordinary courts to exercise this power and to enrich the jurisprudence on this issue. The article has also shed light on the controversial issue of Shari'a as the source of legislation and the implication of such status. However, this case revealed the necessity for reforming this area of law to eliminate any conflict between the Criminal Act and the Child Act by addressing the issue legislatively. It also articulated the necessity for taking measures to enhance the legal methodology in Sudan as serious defects are manifest in areas of judicial reasoning, statutory interpretation and judicial review. 